\title{
The physical and mechanical properties of magnesium oxychloride cement-based materials
}

\author{
Szymon Malinowski, Justyna Jaroszyńska-Wolińska \\ Katedra Geotechniki, Wydziat Budownictwa i Architektury, Politechnika Lubelska, \\ e-mail:s.malinowski@pollub.pl,j.wolinska@gmail.com
}

\begin{abstract}
The aim of this paper was the examination of the physical-mechanical properties of Sorel cement-based material. In the experimental part the effect of polypropylene fibers (PP) and micro-silica on properties of composite materials were studied. The results show that addition of these modifiers increases compressive strength, waterproofing and resistance against corrosion. Increase of compressive strength was observed from both addition of PP and micro-silica. PP resulted in an increase in compressive strength of $0,72 \mathrm{MPa}$, whereas addition of micro-silica caused an increase of $17,5 \%$ compared to pure Sorel's cement. Improvement of water-tightness was observed in both additions of PP and micro-silica. Weight loss of samples with PP addition to the concrete after a 7-day bath in an aggressive solution of $5 \% \mathrm{HCl}$ was less than about $20 \%$.
\end{abstract}

Keywords: Magnesium oxychloride cement, Polypropylene fibers, micro-silica, mechanical properties, physical properties

\section{Introduction}

One of the mineral binders is Sorel's cement (SC) also known as magnesium oxychloride cement (MOC). It is formed by a mixture of powdered magnesium oxide $(\mathrm{MgO})$ and a solution of magnesium chloride $\left(\mathrm{MgCl}_{2}\right)$. The first of the cement components is obtained by decomposition of magnesium carbonate $\left(\mathrm{MgCO}_{3}\right)$ [1] or dolomite [2] at a temperature of $750^{\circ} \mathrm{C}$. The quality of the oxide obtained in this process is strongly dependent on the duration of the calcination process and the size of magnesium carbonate particles used [1]. Depending on the temperature used in the product has various crystalline phases. At room temperature phases 3 and 5 are formed, while in temperatures above $100^{\circ} \mathrm{C}$ phases 2 and 9 appear. These phases with various amount of magnesium hydroxide and water are shown in the following formulas [2]:

$$
\begin{aligned}
& 2 \mathrm{Mg}(\mathrm{OH})_{2} * \mathrm{MgCl}_{2} * 2 \mathrm{H}_{2} \mathrm{O} \\
& 2 \mathrm{Mg}(\mathrm{OH})_{2} * \mathrm{MgCl}_{2} * 4 \mathrm{H}_{2} \mathrm{O} \\
& \left.2 \mathrm{Mg}(\mathrm{OH})_{2} * \mathrm{MgCl}_{2} * 5 \mathrm{H}_{2} \mathrm{O} \text { (phase } 2\right) \\
& \left.3 \mathrm{Mg}(\mathrm{OH})_{2} * \mathrm{MgCl}_{2} * 8 \mathrm{H}_{2} \mathrm{O} \text { (phase } 3\right) \\
& 5 \mathrm{Mg}(\mathrm{OH})_{2} * \mathrm{MgCl}_{2} * 8 \mathrm{H}_{2} \mathrm{O} \text { (phase 5) } \\
& 9 \mathrm{Mg}(\mathrm{OH})_{2} * \mathrm{MgCl}_{2} * 4 \mathrm{H}_{2} \mathrm{O} \\
& 9 \mathrm{Mg}(\mathrm{OH})_{2} * \mathrm{MgCl}_{2} * 5 \mathrm{H}_{2} \mathrm{O} \\
& 9 \mathrm{Mg}(\mathrm{OH})_{2} * \mathrm{MgCl}_{2} * 6 \mathrm{H}_{2} \mathrm{O} \text { (phase 9) [2] }
\end{aligned}
$$

Responsible for the compressive strength of SC is creation of phases 3 and 5[3]. Although the accurate phase formation mechanism is not known today, there are theories describing the formation of the hydrates. The theory proposed by Ved et al.[4] says that 
formed end phases are followed by polymerization reaction ions such as [HO-Mg-O]', $\left[\mathrm{Mg}\left(\mathrm{H}_{2} \mathrm{O}\right)_{6-1}{ }^{*} \mathrm{Cl}\right]^{-},\left[\mathrm{Mg}\left(\mathrm{H}_{2} \mathrm{O}\right)_{6-\mathrm{x}}{ }^{*} \mathrm{OH}\right]^{+}, \mathrm{OH}^{-}, \mathrm{Cl}^{-}, \mathrm{H}^{+}$, or $[\mathrm{MgOH}]^{+}$. A less complicated mechanism was proposed by Balinski and his coworkers [5]. This mechanism explained that simple ions such as $\mathrm{Mg}^{2+}, \mathrm{Cl}^{-}$and $\mathrm{OH}^{-}$are responsible for creating $\mathrm{SC}$ crystalline phases. However, the theory developed by Zhang Zhenyu [6] explains that phases 3 and 5 are created by reactions between $\mathrm{MgO}$ or $\mathrm{Mg}^{2+}$ and a solution of $\mathrm{MgCl}_{2}$ [3]. The chemical reactions which describe the formation of these phases are submitted in following equations:

$$
\begin{aligned}
& 3 \mathrm{Mg}^{2+}+\mathrm{Cl}^{-}+5 \mathrm{OH}^{-}+4 \mathrm{H}_{2} \mathrm{O} \rightarrow \mathrm{Mg}_{3}(\mathrm{OH})_{5} \mathrm{Cl}^{*} 4 \mathrm{H}_{2} \mathrm{O}, \\
& 2 \mathrm{Mg}^{2+}+\mathrm{Cl}^{-}+3 \mathrm{OH}^{-}+4 \mathrm{H}_{2} \mathrm{O} \rightarrow \mathrm{Mg}_{2}(\mathrm{OH})_{3} \mathrm{Cl}^{*} 4 \mathrm{H}_{2} \mathrm{O}[7] .
\end{aligned}
$$

MOC has many advantages compared with Portland cement. It is unaffected by oil, grease or paints, has high fire resistance, low thermal conductivity and good resistance to abrasion [1]. The hardening process of SC is faster than in the case of Portland cement. One of the most important advantages of SC is its resistance to high temperatures [8]. The physical and chemical properties of concrete are significantly affected by the molar ratios of the reactants used in the formation process such as: $\mathrm{MgO} / \mathrm{MgCl}_{2}$ or $\mathrm{H}_{2} \mathrm{O} / \mathrm{MgCl}_{2}$. They affect mainly the compressive strength of concrete. Increasing the amount of water used in the hardening process decreases the compressive strength of the obtained material. Increasing the value of the molar ratio $\mathrm{MgO} / \mathrm{MgCl}_{2}$ results in more hardy concrete. Phase 3 of $\mathrm{SC}$ is obtained when the value of this molar ratio is greater than 11 . This phenomenon results in the cement setting process time being longer. The most favorable values of molar ratios of reactants are 13 and 12 respectively for $\mathrm{MgO} / \mathrm{MgCl}_{2}$ and $\mathrm{H}_{2} \mathrm{O} / \mathrm{MgCl}_{2}$ [1].

An important area of research into $\mathrm{SC}$ is the impact of modifiers on its properties. Additives can change both physical and mechanical properties of concrete such as compressive strength or water-tightness. In the last decade many advances have been made to increase the resistance to water of SC. For this purpose in the production of SC concrete is added phosphorous acid $\left(\mathrm{H}_{3} \mathrm{PO}_{4}\right)$ or soluble phosphates alkali metals, ferric, aluminum or ammonium[9] e.g. $\mathrm{NaH}_{2} \mathrm{PO}_{4}, \mathrm{Mg}_{2}\left(\mathrm{PO}_{4}\right)_{3}, \mathrm{Na}_{3} \mathrm{PO}_{4}$ or $\mathrm{NaH}_{2} \mathrm{PO}_{4}$ [7]. Studies indicated that for increased water-tightness of concrete based on $\mathrm{SC}$, small amount of phosphorous must be added. The actions of these modifiers are based on increasing the stability of phase 5 in water solution. The main components responsible for better resistance to water are $\mathrm{H}_{2} \mathrm{PO}_{4}{ }^{-}$, $\mathrm{HPO}_{4}{ }^{2-}$, or $\mathrm{PO}_{4}{ }^{3-}$, which are created in an ionization process of soluble phosphorous salts [9]. Addition of phosphorous acid may influence microstructure and the mechanical properties of concrete. FTIR analysis has shown that addition of phosphorous acid causes creation of the binder $\mathrm{P}=\mathrm{O}$ located in the group $\mathrm{PO}_{4}{ }^{3-}$. After adding this acid the surface of the concrete has needle-shaped crystals. The presence of phosphorous acid when concrete is created influences negatively on the mechanical properties and cement setting process time [10]. Water-tightness of Sorel's cement may be changed by the addition of organic emulsion, e.g. stearic acid-styrene acrylic acid copolymer. This emulsion structure has a large number of hydrophobic groups forming on the concrete structure a hydrophobic layer [8]. In order to increase the compressive strength of SC concrete is added granite waste. It is characterized by high durability and resistance to scratches, moisture, cracks, spills and both high and low temperature. Therefore concrete with the addition of granite wastes has greater plasticity and mechanical properties. Addition of granite wastes influences also corrosion processes in this material [11].

Among the polymeric fibers used as modifiers of SC, the most important are polypropylene fibers (PP). Chopped fibres of pure polypropylene are chemically inert and can generate hydrophilic effects ensuring ease of wetting contact with water in the concrete 
mix. The addition of polypropylene fibres to concrete mixtures causes reduction of shrinkage cracks and micro-cracks due to the settling of plasticisers, eliminates the need for steel mesh, reduces water absorption and water permeability, limits penetration of concrete by chemical substances, limits corrosion of concrete and reinforcing steel, increases frost and abrasion resistance, increases compression and flexural strengths by more than $10 \%$ to increase toughness and resistance to crushing, improves consistency and uniformity of concrete, increases workability and resistance to segregation of ingredients and increases the durability of concrete and reinforced concrete [12].

The fibres formed in the concrete mix comprise a spatial grid, which acts as a micro wire mesh preventing contraction. Elimination of shrinkage cracks in the concrete improves the tightness and reduces penetration to protect concrete structural reinforcement against corrosion. It also prevents aging of concrete and increases frost resistance.

The addition of polypropylene fibres for concrete improves the homogeneity. Concrete with fibres uniformly distributed in the mass retains the mixing water in the whole volume of the mixture by reducing the gravity fall of heavier components and excessive outflow of water which takes the form of a milky solution on the surface of the concrete element. This property of the fibres increases the strength of the surface at very high temperature. You do not need special care to prevent cracking of the concrete surface due to excessive evaporation of water but the surface region of the concrete mix stays moist for a long time until setting. Polypropylene fibres uniformly distributed throughout the mass of concrete limit segregation of the ingredients in the mix and prevent the formation of air voids. Concrete with fibre is more resistant to abrasion. Also fibre increases by $10 \%$ concrete tensile strength in bending and $14 \%$ in compressive strength. Fibre concrete has the ability to self-support and not break at cracks and, therefore, may be used in pre-fabrication with increased resistance to damage during transport and handling. The stabilizing effect of polypropylene fibres makes them useful in the repair of reinforced concrete structures, e.g. gunning.

Micro-silica is produced as waste in the steel industry and in the production of metal silicon, ferrosilicon and other alloys as a result of the reduction of high-purity quartz by carbon arc-resistance furnaces in continuous operation. The quartz evaporates as $\mathrm{SiO}$ and is re-oxidized to $\mathrm{SiO}_{2}$ by contact with oxygen in the cooler parts of the furnace as the amorphous form of silica and condensed in the form of microscopic particles with grain size of approximately $0.1 \mathrm{~mm}[13]$.

The formation of silica dust can be summarized by the following reactions:

$$
\begin{aligned}
& \mathrm{SiO}_{2}+\mathrm{C} \rightarrow \mathrm{SiO}+\mathrm{CO} \\
& 2 \mathrm{SiO} \rightarrow \mathrm{Si}+\mathrm{SiO}_{2} \\
& 3 \mathrm{SiO}+\mathrm{CO} \rightarrow \mathrm{SiC}+2 \mathrm{SiO}_{2}[14]
\end{aligned}
$$

The amount of $\mathrm{SiO}_{2}$ in the dusts output by these processes increases in proportion to the amount of silicon in the melt. For instance, ferrosilicon alloys containing $50 \%$ or $75 \%$ silicon have respectively $61-77 \%$ and $84-88 \%$ silica dust and the metal silicon has up to $98 \%$ silica in the dust.

Initially, the interest in silica dust stemmed mainly from considerations of environmental protection and savings by replacing part of cement with this waste material. The usefulness of micro-silica in concrete technology found its practical reflection a quarter of a century ago. In 1971, structural concrete made in the mill Fisk in Norway used silica fume. In the same year the company "Sika Chemie" received the first patent for micro-silica and super plasticizers as cement additives. The first projects using silica fume concrete production in the United States and Canada took place in the early 1980s. Interest 
in the subject of micro-silica dust is constantly increasing as an attractive material for use in concrete especially in the era of super plasticizers to allow their dosage to be increased. The result of this cooperation is concrete with high durability and strength.

In Poland micro-silica is available as a dry particulate or as colloidal silica being an aqueous suspension of air and silica with or without additives. To complete the picture it should be added that there are other forms of micro-silica but they are not widely used in construction, for example silica granules, silica slurry and clumped silica dust [13].

MOC in view of its properties may be used in many areas of industry and science. It is widely used in architecture for door frames, beams [11] or marble floors [1], for production of grinding wheels, fireproof materials and thermal insulation materials [11]. SC may be used in environmental protection for water treatment with methyl orange, bromophenol blue[15] and other synthetic dyes designated as RY-145, RR-194, RB-B of molecular structure presented in figure 1 [16]. In view of its good adsorption properties, SC may be used for preconcentration of ions U(VI) [17].

a)

b)<smiles>O=C(O)COS(=O)(=O)Nc1nc(Cl)nc(Nc2cccc(S(=O)(=O)O)c2)n1</smiles>

c)

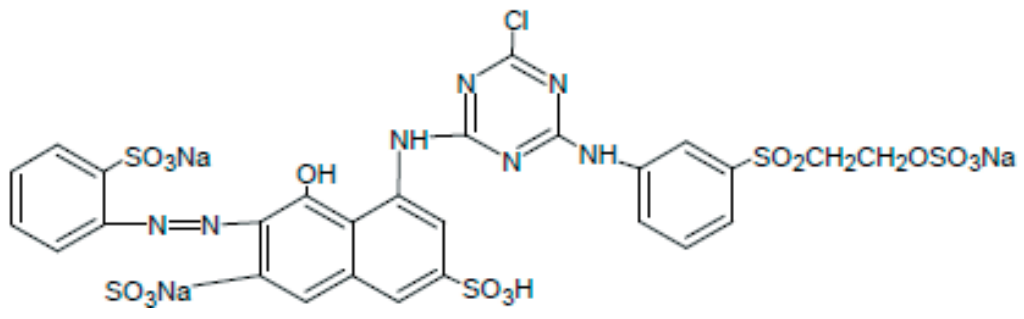

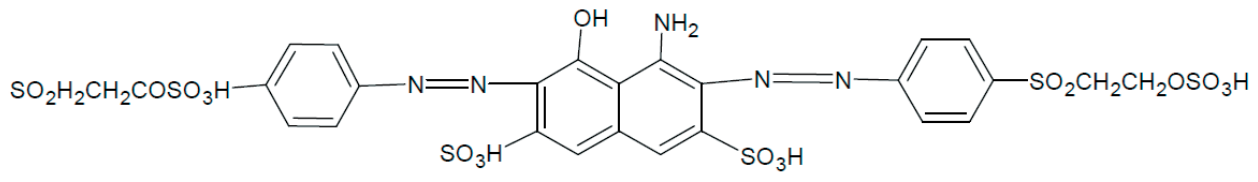

Fig. 1. Structure of a) RY-145, b) RR-194, c) RB-B 


\section{Materials and methods}

This research was carried out on samples of cubic dimensions $150 \times 150 \times 150 \mathrm{~mm}^{3}$. The preparation of concrete samples for testing was based on PN-EN12390-2 [18]. The research used three kinds of samples: samples containing pure Sorel's cement (PSC), samples containing Sorel's cement with addition of polypropylene fibers (PPFSC) and samples containing Sorel's cement with addition of micro-silica (MSSC). The chemical composition of the samples examined in this paper is presented in table 1 . The physical properties of the PP used are presented in table 2. Fibres can be added to concrete before or during mixing but the best effect is obtained by adding polypropylene fibres during the mixing of the gravel, sand and water to form an aggregate but prior to adding the cement. Mixing concrete with fibre for 5 minutes at 12 rotations/minute guarantees their uniform distribution. Polypropylene fibres can also be added to ready mix concrete in the mixer. The concrete should be mixed for at least 5 minutes. The recommended amount of fibre per $1 \mathrm{~m}^{3}$ of concrete is $0.6-0.9 \mathrm{~kg}$. Changing the proportions of the other ingredients is not necessary. Concrete with polypropylene fibres does not require any special handling or treatment other than the routine required by the Polish Standard, and the surfaces of fibre concrete elements can be aligned and trowelled using conventional tools designed for this purpose.

Table 1. Chemical composition of samples.

\begin{tabular}{llllll}
\hline 1 & & 2 & & 3 & \\
\hline Chemical & Quantity & Chemical & Quantity & Chemical & Quantity \\
Magnesium oxide & $6720 \mathrm{~g}$ & Magnesium oxide & $4320 \mathrm{~g}$ & Magnesium oxide & $4320 \mathrm{~g}$ \\
Magnesium chloride & $3033 \mathrm{~g}$ & Magnesium chloride & $1950 \mathrm{~g}$ & Magnesium chloride & $1950 \mathrm{~g}$ \\
Water & $2660 \mathrm{ml}$ & Water & $2750 \mathrm{ml}$ & Water & $1500 \mathrm{ml}$ \\
Sand $(0-2 \mathrm{~mm})$ & $9492 \mathrm{~g}$ & Sand $(0-2 \mathrm{~mm})$ & $7120 \mathrm{~g}$ & Sand $(0-2 \mathrm{~mm})$ & $7120 \mathrm{~g}$ \\
Gravel $(2-8 \mathrm{~mm})$ & $14240 \mathrm{~g}$ & Gravel $(2-8 \mathrm{~mm})$ & $10680 \mathrm{~g}$ & Gravel $(2-8 \mathrm{~mm})$ & $10680 \mathrm{~g}$ \\
Zinc fluorosilicate & $8,6 \mathrm{ml}$ & Polypropylene fibers & $66,8 \mathrm{~g}$ & Micro-silica & $62,7 \mathrm{~g}$ \\
& & Zinc fluorosilicate & $8,6 \mathrm{ml}$ & Zinc fluorosilicate & $8,6 \mathrm{ml}$ \\
\hline
\end{tabular}

Table 2. Physical properties of PP.

\begin{tabular}{lllll}
\hline $\begin{array}{l}\text { Length } \\
{[\mathrm{mm}]}\end{array}$ & $\begin{array}{l}\text { Diameter } \\
{[\text { micron }]}\end{array}$ & $\begin{array}{l}\text { Density } \\
{\left[\mathrm{g} / \mathrm{cm}^{3}\right]}\end{array}$ & $\begin{array}{l}\text { Tensile strength } \\
{\left[\mathrm{kN} / \mathrm{mm}^{2}\right]}\end{array}$ & $\begin{array}{l}\text { Melting point } \\
{\left[{ }^{\circ} \mathrm{C}\right]}\end{array}$ \\
\hline 19 & 30,5 & 0,91 & $0,32-0,42$ & 168 \\
\hline
\end{tabular}

\subsection{Examination of compressive strength}

Examination of the compressive strength of concrete was carried in machine "Controls". Compressive strength testing was performed after 28 days of setting. The moist samples were dried and placed in a testing machine on a platen. Cubic samples were adjusted so that the load was applied perpendicularly to the direction of moulding. The increase in tension was between 0.2 to $1.0 \mathrm{MPa} / \mathrm{s}$. The stress continued until destruction of the samples. The highest load to destruction was noted. The compressive strength was calculated from the formula:

$$
f_{c}=\frac{F}{A_{C}}[\mathrm{MPa}]
$$


where: $F$ - maximum destructive force $[\mathrm{kN}], A_{c}$ - cross-sectional area of the sample experiencing the compressive force $\left[\mathrm{m}^{2}\right]$.

\subsection{Examination of water tightness}

Water resistance was tested on samples of the same dimensions as previously. The water at the surface of the sample had a diameter of $100 \mathrm{~mm}$ and the time to exhaust the water reservoir through penetration of the concrete was measured.

\subsection{Examination of acceleration corrosion}

The research into acceleration corrosion of concrete with both SC and various modifiers with SC was investigated using a 5\% solution of hydrochloric acid and $15 \%$ solution of road salt. The degree of corrosion was calculated on the basis of the difference in sample mass before and after immersion of the sample in a bath of the aggressive environment. Before re-weighing, samples were dried. Measurements were taken after 24 hours and 7 days. Solution road salt, used for research, included sodium chloride, sulphates, potassium ferrocyanide $\left(\mathrm{K}_{4} \mathrm{FeCn}_{6}\right)$ (acting as an anti-agglomeration substance).

\section{Results and discussion}

\subsection{Examination of compressive strength}

Compressive strength values of the Sorel cement-based materials can be determined according to DIN EN 206-1 (PN-EN 206-1:2003 [19]) as shown in table 3 and figure 2:

Table 3. Results of Compressive strength tests (PSC-Pure Sorel's Cement, PPFSC-Sorel's Cement with addition of PP fibers, MSSC-Sorel's with addition of micro-silica).

\begin{tabular}{llll}
\hline Material & Sample Number & Destructive Force $[\mathrm{kN}]$ & Compressive strenght [MPa] \\
\hline \multirow{3}{*}{ PSC } & 1 & 226,1 & 10,05 \\
& 2 & 215,50 & 9,58 \\
& 3 & 222,40 & 9,88 \\
\hline \multirow{2}{*}{ PPFSC } & 1 & 61,00 & 2,71 \\
& 2 & 57,70 & 2,56 \\
& 3 & 47,70 & 2,12 \\
\hline \multirow{3}{*}{ MSSC } & 1 & 232,56 & 10,8 \\
& 3 & 213,18 & 9,99 \\
& 3 & 234,71 & 10,9 \\
\hline
\end{tabular}

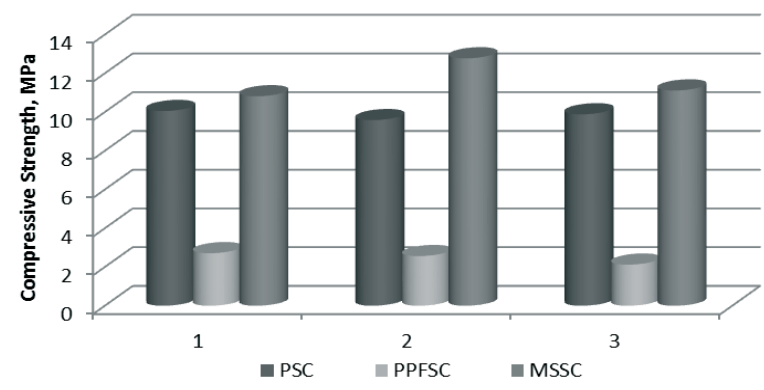

Fig. 2. Chart of compressive strengths vs. material composition (PSC-Pure Sorel's Cement, PPFSCSorel's Cement with addition of PP fibers, MSSC-Sorel's with addition of micro-silica). 
The data shows that both addition of PP and micro-silica causes an increase in the compressive strength of the tested materials. The compressive strength of PSC, PPSCS and MSSC are respectively about $9 \mathrm{MPa}, 10 \mathrm{MPa}$ and $11 \mathrm{MPa}$. Modification of concrete by micro-silica causes an increase in compressive strength about $2 \mathrm{MPa}$. Particles of microsilica may place themselves in the interstices of the concrete and react with particles of cement resulting in increased stability due to a formed crystalline skeleton [18].

\subsection{Examination of water-tightness}

The influence of modifiers on the water-tightness of Sorel cement-based materials is shown in table 4.

Table 4. Water penetration of Sorel cement based materials (PSC-Pure Sorel's Cement, PPFSC-Sorel's Cement with addition of PP fibers, MSSC-Sorel's with addition of micro-silica).

\begin{tabular}{ll}
\hline Material & Water Penetration $[\mathrm{mm}]$ \\
\hline PSC & completely drained $*$ \\
PPFSC & completely drained $* *$ \\
MSSC & completely drained $* *$ \\
\hline
\end{tabular}

(*sample after 1 day, ${ }^{* *}$ sample after 2 days)

The addition of PP and micro-silica to SC enhances the water-tightness of these concretes. Modification of the composition of SC causes prolongation of the time for penetration by water of all samples. The decrease in wettability of PPFSC is likely to be caused by the hydrophobic nature of the PP fibers. On the other hand, both the PP fibers and micro-silica may place themselves inside the pores of the concrete and, thus, decrease simple penetration of water.

\subsection{Examination of acceleration corrosion}

\subsubsection{Corrosion in $5 \%$ solution of hydrochloric acid}

Table 5 and figure 3 presents the result of accelerated corrosion tests of samples exposed to a solution of $5 \% \mathrm{HCl}$.

Table 5. Result of acid corrosion tests $(5 \% \mathrm{HCl})$ (PSC-Pure Sorel's Cement, PPFSC-Sorel's Cement with addition of PP fibers, MSSC-Sorel's with addition of micro-silica).

\begin{tabular}{lllllll}
\hline Material & $\begin{array}{l}\text { Sample } \\
\text { number }\end{array}$ & $\begin{array}{l}\text { Initial } \\
\text { weight } \\
{[\mathrm{g}]}\end{array}$ & $\begin{array}{l}\text { Weight after } \\
24 \mathrm{~h} \\
{[\mathrm{~g}]}\end{array}$ & $\begin{array}{l}\text { Weight Loss } \\
\text { after } 24 \mathrm{~h} \\
{[\%]}\end{array}$ & $\begin{array}{l}\text { Weight after } \\
7 \text { days } \\
{[\mathrm{g}]}\end{array}$ & $\begin{array}{l}\text { Weight Loss } \\
\text { after 7 days } \\
{[\%]}\end{array}$ \\
\hline \multirow{3}{*}{ PSC } & 1 & 808,28 & 696,64 & $-13,81$ & 695,57 & $-13,94$ \\
& 2 & 792,43 & 702,48 & $-11,35$ & 701,38 & $-11,49$ \\
& 3 & 877,23 & 791,43 & $-9,78$ & 790,30 & $-9,91$ \\
\hline \multirow{3}{*}{ PPFSC } & 1 & 930,69 & 852,07 & $-8,45$ & 851,50 & $-8,51$ \\
& 2 & 770,74 & 700,61 & $-9,01$ & 698,93 & $-9,32$ \\
\hline \multirow{3}{*}{ MSSC } & 3 & 775,51 & 689,48 & $-11,09$ & 687,62 & $-11,33$ \\
& 2 & 762,30 & 656,41 & $-13,89$ & 656,04 & $-13,96$ \\
& 3 & 735,36 & 664,07 & $-9,69$ & 643,93 & $-12,43$ \\
\hline
\end{tabular}




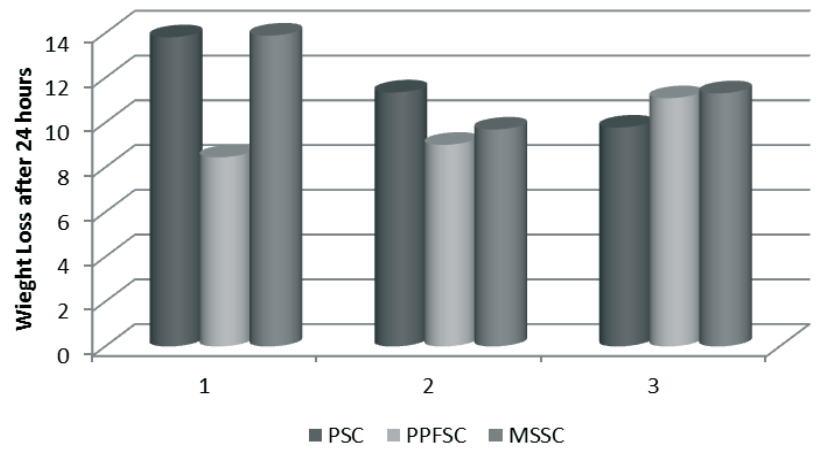

Fig. 3. Chart of changes in weight after exposure to solution of 5\% $\mathrm{HCl}$ (PSC-Pure Sorel's Cement, PPFSC-Sorel's Cement with addition of PP fibers, MSSC-Sorel's with addition of micro-silica).

Addition of PP and micro-silica decrease the corrosion process in a 5\% solution of $\mathrm{HCl}$. In all cases addition of a modifier caused decrease weight loss in the sample mass after immersion in the corrosive solution. Addition of PP caused a decrease of approximately $6 \%$, whereas the presence of micro-silica in the sample composition resulted in only a slight decrease in weight sample. It was observed that significant weight loss was seen within the first 24 hours of immersion while the following 6 days demonstrated small difference in weight of the sample. This phenomenon is caused by a decrease in the concentration of the $5 \%$ solution $\mathrm{HCl}$ with time.

\subsubsection{Corrosion in $15 \%$ solution of road salt}

Figure 4 and table 6 present data on samples of Sorel cement based materials in an environment of road salt and the resulting corrosion.

Table 6. Results of corrosion tests in a 15\% solution of road salt (PSC-Pure Sorel's Cement, PPFSCSorel's Cement with addition of PP fibers, MSSC-Sorel's with addition of micro-silica).

\begin{tabular}{lllllll}
\hline Material & $\begin{array}{l}\text { Sample } \\
\text { number }\end{array}$ & $\begin{array}{l}\text { Initial } \\
\text { weight } \\
{[\mathrm{g}]}\end{array}$ & $\begin{array}{l}\text { Weight after } \\
24 \mathrm{~h} \\
{[\mathrm{~g}]}\end{array}$ & $\begin{array}{l}\text { Weight loss } \\
\text { after } 24 \mathrm{~h} \\
{[\%]}\end{array}$ & $\begin{array}{l}\text { Weight after } \\
7 \text { days } \\
{[\mathrm{g}]}\end{array}$ & $\begin{array}{l}\text { Weight loss } \\
\text { after 7 days } \\
{[\%]}\end{array}$ \\
\hline \multirow{3}{*}{ PSC } & 1 & 823,73 & 825,74 & 0,24 & 825,28 & 0,19 \\
& 2 & 822,05 & 822,88 & 0,10 & 823,08 & 0,12 \\
\hline \multirow{3}{*}{ PPFSC } & 3 & 854,48 & 856,17 & 0,20 & 856,23 & 0,20 \\
\hline \multirow{3}{*}{ MSSC } & 1 & 911,49 & 911,78 & 0,03 & 912,48 & 0,11 \\
& 3 & 846,18 & 847,64 & 0,17 & 848,50 & 0,27 \\
& 2 & 829,62 & 830,66 & 0,13 & 831,18 & 0,19 \\
\hline
\end{tabular}

Sodium chloride induced corrosion causes a decrease in durability and strength of concrete through loss of material due to chemical leaching. It also causes weight gain due to the penetration and build up of chloride salt crystals on the surface of the binder and in the pores of the material. In essence, in terms of mass, we have two competing mechanisms - mass loss through erosion of cement materials vs. mass gain from formation of interstitial crystals of $\mathrm{NaCl}$ 


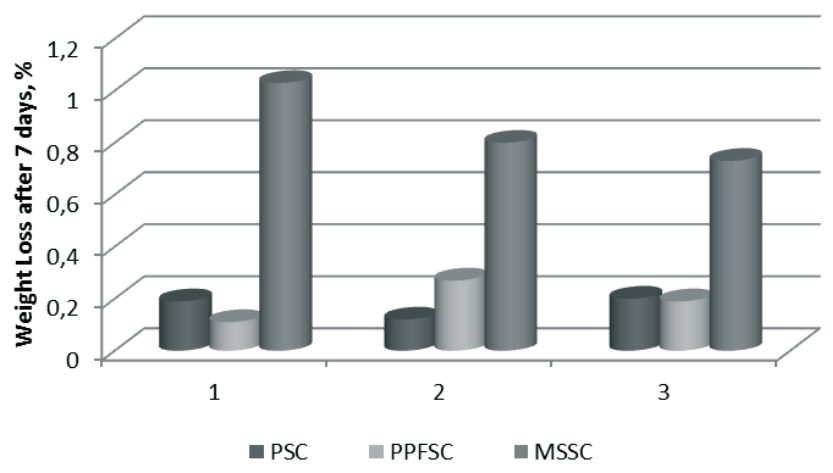

Fig. 4. Chart of mass change in samples exposed to $15 \%$ solution of road salt (PSC-Pure Sorel's Cement, PPFSC-Sorel's Cement with addition of PP fibers, MSSC-Sorel's with addition of micr-silica).

\section{Conclusions}

- The use of additives in the form of micro-silica and polypropylene fibers significantly alters the properties of magnesium oxychloride cement- based materials.

- Micro-silica added to Sorel cement confers new properties to the material strength and beneficially affects performance parameters of the material. The addition increases the compressive strength by $1.7 \mathrm{MPa}$ being $17.5 \%$ of the 'pure' (no additive) material and reduces water absorption. The fine particles of micro-silica applied to the matrix target material fill the voids between the aggregates. They reduce the mixing water content in the binder and increase the density.

- The addition of PP significantly reduces shrinkage cracks and micro cracks.

- Studies of water-tightness confirmed that Sorel cement has poor water resistance. Both micro-silica and polypropylene fibers were shown to reduce water absorption and permeability of the material, the reduced penetration being likely to significantly limit corrosion. It is not recommended, however, to use more fiber than the determined optimum as use of large amounts of polypropylene fibers in order to make better use of waste did not yield positive results.

- The addition of PP causes decrease of acid corrosion.

\section{Acknowledgements}

We acknowledge support from Polish Ministry of Science and Higher Education within the statutory research number $\mathrm{S} / 12 / 2015$.

\section{References}

1 Li. Z., Chau C.K., Influence of molar ratios on properties of magnesium oxychloride cement. Cement and concrete research 37 (2007) 866-870.

2 Liu Z., Wang S, Huang J., Wei Z., Guan B., Fang J. Experimantal investigation on properties and microstructure of magnesium oxychloride cement prepared with caustic magnesite and dolomite. Construction and Building Material 85(2015) 247-255.

3 Dehua D., Chanmei Z., The formation mechanism of the hydrate phases in magnesium oxychloride cement. Cement and Conrete research 29 (1999) 1365-1371. 
4 Ved E.I., Zharow E.F., Van P. H. Mechanism of magnesium oxychloride fotmations during the hardenind of magnesium oxychloride cements. (Russ) Zhurnal Prikladnoi Khimii 1976 (49) 2154.

5 Bilinski H., Matkovic B., Mazuravic C., Zunic T.A. The formation of magnesium oxychloride phases in the system $\mathrm{MgO}-\mathrm{MgCl}_{2}-\mathrm{H}_{2} \mathrm{O}$ and $\mathrm{NaOH}-\mathrm{MgCl}_{2}-\mathrm{H}_{2} \mathrm{O}$. Journal of American Ceramic Society 1984 (67) 266.

6 Z. Zhenyu, D Changlu, Z. Quanchand, L. Bozhi, L. Weilin, A study on the formation mechanism of 5 phase and 3 phase. (Chinese) China Science (B) 1991 (1) 82.

7 Zhou Z., Chen H., Li Z., Li H. Simulation of the properties of $\mathrm{MgO}-\mathrm{MgCl}_{2}-\mathrm{H}_{2} \mathrm{O}$ system by thermodynamic method. Cement and concrete research 68 (2015)105-111.

$8 \mathrm{Li}$ J., Li G., Yu Y. The influence of compound additive on magnesium oxychloride cement/urban refuse floor tile. Construction and building materials 22 (2008)521-525.

9 Deng D. The mechanism for soluble phosphates to improve the water resistance of magnesium oxychloride cement. Cement and concrete research 33 (2003) 1311-1317.

10 Tan Y., Liu Y., Grover L. Effect of phosphoric acid on the properties of magnesium oxychloride cement as a biomaterial. Cement and concrete research 56 (2014) 69-74.

11 Li Y., Yu H., Zheng L., Wen J., Wu Ch., Tan Y. Compressive strength of fly ash magnesium oxychloride cement containg granite wastes. Construction and building materials 38 (2013) 1 7.

12 Cifuentes H., Garcia F., Maeso O., Medlina F. Influence of the properties fibres on the fracture behavior of low-, normal-, anf high-strength FRC. Construction and Building Materials 45 (2013) 130-137.

13 Jasiczak J., Mikołajczak P. Technologia betonu modyfikowanego domieszkami i dodatkami. politechnika Poznańska (2003).

14 Mąkosa J. Nowa tendencja wykonywania betonów na bazie krzemionki. Materiały budowlane 8 (1992).

15 El-Gamal S.M.A., Amin M.S., Ahmed M.A. Removal of methyl orange and bromophenol blue dyes from aqueous solution using Sorel's cement nanoparticles. Journal of Environmental Chemical Engineering 3 (2015) 1702-1712.

16 Hassan S.S.M, Awwad N.S., Aboterica A.H.A. Removal of synthetic reactive dyes from textile wastewater by Sorel's cement. Journal of Hazardous Materials 162 (2009) 994-999.

17 Awwad N.S., Daifullah A. A. M. Preconcentration of U(VI) from aqueous solution after sorption using Sorel's Cement in dynamic mode. Journal of Radioanalytical and Nuclear Chemistry, Vol. 264, No. 3 (2005) 623-628.

18 PN-EN 12390-2, Badania betonu - Część 2: Wykonywanie i pielęgnacja próbek do badań wytrzymałościowych.

19 PN-EN 206-1:2003, Beton Cz. I Wymagania. Właściwości. Produkcja. Zgodność. 